\title{
The Geographical Dimensions of the Development of the Fish keeping and Canning Industry in the Kingdom of Saudi Arabia
}

\author{
Hoda bint Mansour Al Turki* \\ Department of Geography, Saudi Arabia \\ Submission: November 21, 2018; Published: December 10, 2018 \\ *Corresponding author: Hoda bint Mansour Al Turki, Department of Geography, Saudi Arabia
}

\section{Abstract}

The food industry is of great importance to the Saudi economy. The Saudi food sector is characterized with quality and vulnerability due to its being a manufacturing industry. The number of food industry establishments in Saudi Arabia reached about 940 establishments in 2015. The fish industry in Saudi Arabia has witnessed a significant development in recent years and has increased its activity as a result of the increase in per capita income, which has led to a change in food behavior. Household expenditure in the Kingdom is increasing on food, and the consumption of fish and crustaceans is 59\% Arabian Gulf States. Fish and marine fish are the most useful meat for the human body and are the source of many nutrients such as protein, iron, calcium and phosphorus. The number of fish factories in the Kingdom reached about 27 factories in 2016 , employing 8485 workers and investing 3061 million riyals. The production capacity reached 2063868 tons. The factories were established in 9 cities. The majority of fish factories in the Kingdom are medium in both capitals invested and labor force. While a minority (14.8\%) are large for the same criteria. This study focuses on the fish industry in terms of industrial construction and spatial distribution of their productive units and their spatial relationship and economics. The fish industry has recently witnessed industrial growth in quantity and quantity. Many factories have started to exploit the secondary products of fish and the use of its remains in the feed industry. The number is suggested to increase to 170 factories in the year $1446 \mathrm{AH}$ (2026), so the study recommends increasing investment in the field of industry and conservation of fish and the exploitation of stocks in commercial quantities.

\section{Introduction}

The food industry is of great importance to the Saudi economy, contributing more than $13.4 \%$ of the total industrial construction in the Kingdom. Therefore, the food industry is very important because of its ability to export and fill a large part of the needs of the Saudi consumer. The food sector in Saudi Arabia is characterized by quality and sophistication because it is a transformational industry. The food industry occupies a vital position within the industrial sector in general and within the manufacturing sector in particular. The number of food industry establishments in the Kingdom of Saudi Arabia reached 640 establishments in 2015. The population growth rate in the Kingdom is about $3.3 \%$, one of the highest growth rates in the Arab countries, and the volume of food expenditure in Saudi Arabia is about $70 \%$ of per capita income, which allows these industries to grow significantly in light of this growing domestic demand. The fish industry in Saudi Arabia has witnessed a significant development in recent years and has increased its activity as a result of the increase in per capita income, which has led to a change in food behavior, where household expenditure in the Kingdom is increasing based on the increase in income Al Ali, [1]. The fish industry is one of the most important food industries in the Kingdom, where fish meat and seafood products are the most important components of the meal in Saudi Arabia, especially with increasing awareness of health.
Fish and marine products are the most useful meat source for the human body and are the source of many nutrients such as protein Iron, vitamin A and B, as well as containing calcium (which is essential for building bones and teeth), phosphorus, iodine and omega-3, which are important for maintaining a healthy body.

However, humans get their nutrients through processed food, raw, so it was necessary to manufacture these foods so that it is palatable and safe and at the same time rich in nutrients Harris 2004. Saudi Arabia ranks second in the Gulf Cooperation Council (GCC) by $20 \%$ of fish and shellfish production in 2002. The percentage of consumption of processed fish and crustaceans is $59 \%$ of total GCC consumption Gulf Organization for Industrial Consulting, 2004. Industrialization plays an important role in the development of fish production. Despite the preference of the Saudi consumer for fresh fish in general, there are many species of fish and other marine organisms that environmental, economic and technical conditions do not allow for fresh consumption. Forms, tastes and uses suit different needs. The seasonality of production and the susceptibility of fish to rapid damage led to the development of methods for storage and preservation of fish, either by drying or salting, where the fish are fermented with salt, and with the development of manufacturing techniques, new conservation methods such as cooling, or freezing, keeping the 
fish frozen for up to six months, which helps to export to remote areas, as well as canning where there are types of fish are suitable only for packaging [2-4].

In the Red Sea there is tuna fish, sardines and mackerel, which are seasonal and these fish suitable for packaging. Smoking is another method in fish manufacturing where the smoke is shed on the fish to cook slowly. Despite the importance of this industry in the Kingdom, the geographical studies that dealt with research and geographical analysis is very few. This study presents the current reality of the fish industry in the Kingdom in details supported by the necessary statistics such as the inventory of factories, employment and production capacity of these factories as well as capital exploited. It also examines the development of this industry during the past years and future plans. The study also investigates the pattern of geographical distribution of this industry in the cities of the Kingdom using four variables known as the basis of measurement which are: enterprises, employment, capital, spatial distribution, and analysis of the economic characteristics of the industry. It also aims at providing a geographical evaluation of the sites of this industry through the application of some methods of measuring the industrial sites. Moreover, it explores the knowledge of the structure, the amount of annual production, the problems and difficulties facing the industry and finally it proposes the necessary recommendations for these issues.

\section{Problem of the study}

The Kingdom of Saudi Arabia has a long coastline and is known for its vast amounts of fish. In the West, there are 2,600 $\mathrm{km}$ long coasts on the Red Sea, $180 \mathrm{~km}$ of the Gulf of Aqaba. Its Red Sea coast is about $80 \%$ of the Red Sea coast, including the length of its coast in the East overlooking the Arabian Gulf which is about $1200 \mathrm{~km}$ Saudi Geological Survey, 2017.According to the statistics of the Ministry of Commerce and Industry, the number of fish factories in the Kingdom reached about 27 factories, and there is little budget in the consumer market represented by the population of the Kingdom of Saudi Arabia, which are more than 31 million people General Authority for Statistics, 2015. Studies indicate an increase in fish per capita in the Kingdom of $8 \mathrm{~kg} /$ year, while the World Health Organization recommends eating $25 \mathrm{~kg}$ fish / person / year Tharwat 2012. With the increase in population growth in the Kingdom, there is a type of food gap between production and consumption of fish, as the production of natural fisheries from the Red Sea and the Arabian Gulf does not exceed 90053 tons for the year 2013 Statistical Yearbook. This production does not meet the growing demand of the population and therefore the trend towards fish farming, where the Ministry of Agriculture established the Fishery Center (Fish Farming Center) in 1982, which is located on the Red Sea coast in northern Abhor [5-8].

This center supports the fish farming industry in the Kingdom and the selection of marine fish species in addition to the evaluation of aquaculture projects. The center also provides the private sector with fish and shrimp pellets. (Ministry of
Agriculture and Water, 2011). The State places great importance to the fish industry by contributing to the development of the fish industry. The Government has exerted many efforts to develop traditional methods of fishing in modern ways through its contribution to the Saudi Deep Sea Fisheries Company, Fish in both Jeddah and Dammam to determine the places where the fish are located in large quantities, to know the fish species, to update the fishing methods, as well as the researches related to their manufacture and conservation and experiences and technical knowledge in this area Abdullah. Therefore, this study examines the fish industry and analyzes the industrial construction and spatial distribution of their productive units and their spatial relationship and economies. The research problem investigated here is the possibility to fill in the gap between the availability of the most important elements of the success of this industry in the Kingdom especially the raw material (fish and marine products) and the productivity of the existing industrial constructions.

\section{Objectives of the study}

This study aims to achieve the following objectives:

a) Present the economic history of the fish industry and its analysis and development in the Kingdom. Produce the knowledge about the geographical distribution of fish plants in the Kingdom.

b) Identify the geographical and economic characteristics of the fish industry in Saudi Arabia.

c) Analyzing the factors of settlement and linking it with the theories of industrial endowment.

\section{Area of the Study}

The study area includes Saudi Arabia, which is located in the Arabian Peninsula, in the extreme south-west of Asia. Its territory is limited to the widths 16 and 32 north, the longitudes 34 and 55 east, and the cancer orbit line (30-23 nm) and its center Saudi Geological Survey. It has an area of about 2 million $\mathrm{km} 2$, and its population in 2015 is about 31,742,308 million people General Organization for Statistics. The endemic cities are the distribution areas required for the study [9-11].

\section{Time Frame of the Study}

The time frame for the study of the fish industry in Saudi Arabia extends to $1389 \mathrm{AH}$, the date of the beginning of the end of the industry in the Kingdom until 1437 AH / 2016, the latest statistics obtained from the Ministry of Commerce and Industry in the Kingdom.

\section{The Approach of the Study}

This study focuses on the fish industry in Saudi Arabia. The descriptive approach will be used to describe the phenomenon under study with the use of quantitative methods in analysis and reasoning (Lorenz curve, standard deviation, geographic correlation coefficient, relative significance coefficient) As well as the use of comparative inductive methodology. The data used in the industrial statistical evidence is issued by the Department of 
Statistics and Industrial Information in the Ministry of Commerce and Industry. The variables of the study include the date of commencement of production of fish factories, their number, production capacity, number of workers, capital invested, and location of all factories. This study relied on the use of statistical programs as methods of analysis and reasoning, including statistical programs such as SPSS and GIS.

\section{Research Topics and Study Literature}

Despite the importance of the fish industry, the geographical studies that dealt with research and geographical analysis are almost rare. On the other hand, the general studies of fish are many, whereas the geographical studies of the industry and fish products are very rare and may be due to the fact that the fish industry classified under the food industry and thus considered as part of it. However, the fish industry and its products were studied as part of the geographical studies that dealt with food industries in the city of Riyadh as in the study Al-Hurra,1409H, which dealt with the classification of food industries in the city of Riyadh in terms of numbers, manpower and capital invested in this industry. This study dealt with the fish industry and its products, which showed the absence of this

type of industry within the city of Riyadh because it is an internal city that does not overlook the sea and this type of industry goes to the raw material (fish quickly damaged).

Al Hurra said that Saudi Fish Company is marketing its production in the city of Riyadh as well as other imported products. Al-Ahmad $(1406 \mathrm{H})$ studied the food industries in the Kingdom of Saudi Arabia and was exposed to the study of the types of food industries. He divided it into food industries using vegetable raw materials, food industries using animal raw materials and food industries using animal and vegetable raw materials. He concluded that it is limited to one factory located in Dammam, where the company takes the task of fishing from the waters of the Arabian Gulf and the Red Sea and then preserves the fish so that they can be used at other times. Abdullah (1989) studied the economics of the food industry in Saudi Arabia in which he discussed the importance of food industries. He also tried to focus on the economic aspect of food industries such as labor and capital.

The study pointed out that the amount of fish that can be caught from the coast of the Kingdom is very much compared with what is actually produced, so much that self-sufficiency can be achieved from some species of fish, and even some production can be exported. However, this study focused primarily on economic characteristics without resorting to analysis and highlighting examples. These two studies have been conducted through a number of years, currently many of the economic features and geographical distribution of the food industries have changed, making their use limited. The study of the Gulf Organization for Industrial Consultancy deals with the food industries in the GCC countries (2004). This study focuses on the general features of the food industries in the GCC countries and dealt with the development of the number of factories, capital invested and employment in food industries in the

\section{GCC countries.}

The fish processing industry in the GCC countries is limited due to the lack of large quantities of fish for processing, and most GCC consumers prefer fresh fish. More than half of the fish processing plants are concentrated in Oman, followed by the UAE and Saudi Arabia with 6 factories in 2003. Tharwat 2012 studied the reality and future of fish wealth in the Kingdom of Saudi Arabia in which fish production, exports and imports of this commodity were studied, along with the fishing methods used. The study also deals with fish farming it focuses on the spatial distribution of this industry and its characteristics as it is a non-geographical study. This current research is considered a specialized study, as far as the researcher is concerned, there is no specialized geographical study in the fish industry and its products in the Kingdom of Saudi Arabia, which adds to the importance of this study, as it fills the gaps in the Arab library to benefit researchers and those interested in industry in the Kingdom of Arabia Saudi.

\section{Second: The Development of the Fish Industry}

The livestock sector and its industries are an extension of the agricultural sector in the Kingdom. This sector has benefited greatly from the state's development and support programs for the agricultural sector. Many fish factories have received much support, attention and encouragement, which enabled them to build their infrastructure. The fish industry in the Kingdom started in 1389 with a factory in Dammam for the fishing and packing of shrimp, with an annual production of 160 tons. The second plant, which was established in $1396 \mathrm{AH}$ in Dammam, also produces fresh and frozen fish in the area of 3000 tons annually of shrimp. A third plant was set up in Jeddah in the same year and is processing and freezing fish around 5500 tons, as well as processing and packing 3,000 tons of shrimp. The fourth plant was established in Jeddah in $1399 \mathrm{AH}$ and it freezes 700 tons of fish.

Table 1: Development of fish and shrimp production (in tons) in Saudi Arabia.

\begin{tabular}{|c|c|c|c|c|c|}
\hline Type & $\mathbf{2 0 1 0}$ & $\mathbf{2 0 1 1}$ & $\mathbf{2 0 1 2}$ & $\mathbf{2 0 1 3}$ & $\mathbf{2 0 1 4}$ \\
\hline $\begin{array}{c}\text { Caught from the } \\
\text { Red Sea }\end{array}$ & 95401 & 70212 & 70052 & 70015 & - \\
\hline $\begin{array}{c}\text { Caught from the } \\
\text { Arabian Gulf }\end{array}$ & 21555 & 25654 & 25262 & 25256 & - \\
\hline $\begin{array}{c}\text { Caught from } \\
\text { international } \\
\text { waters }\end{array}$ & 5 & 5 & 5 & 5 & - \\
\hline $\begin{array}{c}\text { Production of fish } \\
\text { farms }\end{array}$ & 76261 & 76729 & 76502 & 76561 & - \\
\hline Total & 20155 & 15207 & 51111 & 15502 & - \\
\hline
\end{tabular}

Source: Statistical Yearbook, No. 51, Supreme Commission for Statistics, 2015.

The establishment of the Saudi Fish Company in 1403 is a qualitative leap in the fish industry. It was established as a joint stock company, which owns $40 \%$ of the shares in addition to a private sector, that owns $60 \%$ of the shares distributed to the founders (30.4\%) and the public 29.6\%) Abdullah, 1409. The 


\section{International Journal of Environmental Sciences \& Natural Resources}

company was established with a capital of 62 million riyals to invest in the living aquatic resources of the Kingdom's regional and international waters, manufacturing and marketing them inside and outside the Kingdom. Then more factories were established,

but at a slow rate around one or two annually, with a complete stop during the years $1407 \mathrm{AH}, 1420 \mathrm{AH}, 1425 \mathrm{AH}, 1427 \mathrm{AH}, 1431$ $\mathrm{H}$ (Table 1) and (Figures 1 \& 2).

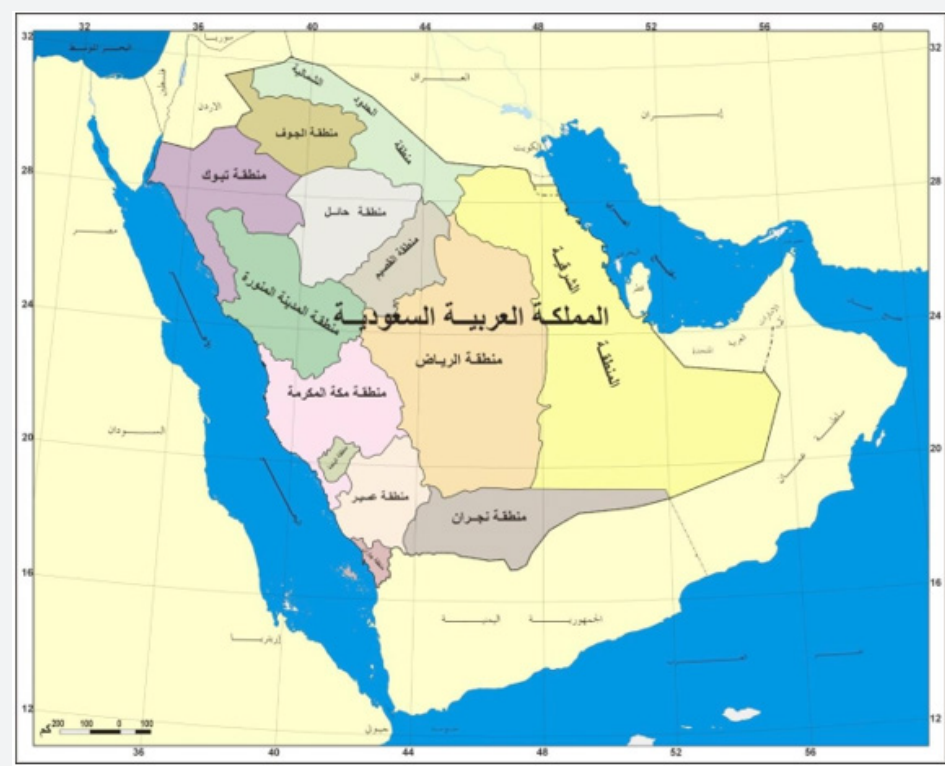

Figure 1: Administrative division of the Kingdom of Saudi Arabia.

Source: Saudi Geological Survey, Kingdom Map 1: 500,000, 1424

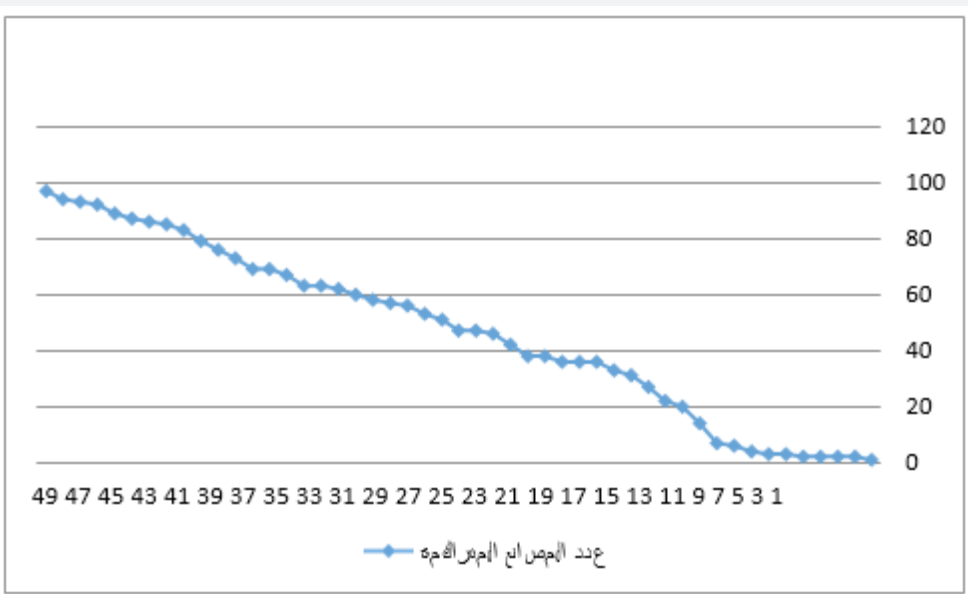

Figure 2: The development of the number of fish factories in the Kingdom of Saudi Arabia.

Table 2: Development of the Number of Fish Factories in the Kingdom of Saudi Arabia During the period (1389 H - $1436 \mathrm{H})$.

\begin{tabular}{|c|c|c|c|c|c|}
\hline Accumulative no. & $\begin{array}{c}\text { Number of factoriesstarted to } \\
\text { produce }\end{array}$ & Years & Accumulative number & $\begin{array}{c}\text { Number of factories started } \\
\text { to produce }\end{array}$ & years \\
\hline 98 & 9 & 9241 & 9 & 9 & 9 \\
\hline 98 & - & 9241 & 4 & 4 & 9831 \\
\hline 92 & 9 & 9243 & 2 & 9 & 9811 \\
\hline 95 & 9 & 9241 & 5 & - & 9211 \\
\hline 91 & 9 & 9284 & 5 & 9 & 9248 \\
\hline 91 & - & 9289 & 1 & 9 & 929 \\
\hline 91 & 9 & 9284 & 1 & 9 & 9 \\
\hline 44 & 9 & 9282 & 1 & & 929 \\
\hline 42 & 2 & 9285 & 1 & 9293 \\
\hline 41 & 4 & 9281 & 94 & 924 \\
\hline
\end{tabular}




\section{International Journal of Environmental Sciences \& Natural Resources}

\begin{tabular}{|l|c|c|c|c|c|}
41 & 9 & 9281 & 94 & 4 & 9248 \\
\hline 41 & Total & - & 94 & - & 9245 \\
\hline
\end{tabular}

Source: Prepared by the researcher based on unpublished statistical data from the Ministry of Commerce and Industry for 2016 and the Statistical Yearbook, Department of Statistics and Industrial Information for 2016.

Before reviewing the development of this industry, fish production in the Kingdom must be addressed because it provides the industry with the most important element of the raw materials necessary for its existence, namely fish and other marine products. The fish production in the Kingdom reached about 90053 tons in 2013 (Table 1) of which 63984 comes from marine fisheries on the Red Sea and the Arabian Gulf, representing $71.1 \%$ of the total production, while 26069 tons of fish farms represent $28.9 \%$ of the total production. Fish production in the Red Sea amounted to 25598 tons, representing $28.4 \%$ of the total marine fisheries production. Production from the Arabian Gulf reached 38386 tons and accounted for $42.6 \%$ of the total marine fisheries production in the Kingdom. The most important types of fish in the Red Sea are Bagha, Hadaba, Albayad, kanad, hamour, tuna and sharks. In the Arabian Gulf there are Shaar, squid Khodar and shrimp. The following section presents the specific features of each historical stage and examines its industrial construction in order to trace of the fish industry and its geographical features (Table 2).

\section{The first phase 1389 - $1402 \mathrm{H}$}

This stage represents the beginning of the stages of establishment and economic construction of most of the economic sectors of the country. It witnessed the growing interest in the government manufacturing industries as well as industry and electricity, which has played a role in the development of economic activities, including industry. Although this phase $(1394 \mathrm{H})$ represents the stage of economic boom in the wake of the unprecedented rise in oil prices, the fish industry has not increased and the rates of development of the factories remained as they are. The fish industry was limited to the freezing and processing of fish and shrimp only as most of the production is sold fresh.

\section{The Second Phase 1403 - 1433 H}

This phase witnessed steady growth in the fish industry in terms of quantity, quality and production. In $1403 \mathrm{AH}$, the Saudi Fish Company was established with the support of the government to encourage and market the fish industry inside and outside the Kingdom. There is no fish and sardine, tuna, canning during this stage because local production does not meet the growing demand for fresh fish. Most Saudi markets were flooded with sardine, tuna, fish fingers and imported fish from abroad, as well as fresh, frozen and imported fish, to fill the deficit in local production, which covered only 40 percent of the domestic consumption of fish Abdullah, 1409.

\section{The Third Phase (1435 - 1437) H}

This stage witnessed industrial growth, especially since most of the factories started in the process of packing and processing the fish in various modern ways, including the manufacture of tuna, sausages, cold meat and fillet of fish meat and fish fingers. New centers for this industry have emerged at this stage: Al-

Layth, Al-Ayoun, Al-Khobar, Qatif, Bahra and Makkah. At this stage, which witnessed the growth of industrial quantity and quality, it turns out that many factories began to invest the by-products of fish, such as the manufacture of shark products by extracting its oil and the use of its residues feed. The waste is used from canning and freezing and smoking in oil extraction, and grinding as a fish powder, poultry and animal feed industry due to its high protein content.

\section{Third: Geographical Distribution of Fish Plants in Saudi Arabia}

Before we discuss the geographical distribution of this industry, it should be noted that despite the Kingdom's efforts to develop the fish industry and increase the local production of fish to exceed the daily need for fresh fish, the Kingdom is still dependent on the completion of its requirements for fish to import from abroad Fresh, frozen and canned fish. It was found that the percentage of factories that use local fish and lakes as basic materials in their products amounted to about 11.5 of the food industry factories. Tuna is the most popular in food processing, accounting for $49 \%$ while the rest of the sea is about 17\% Alhara, 2012. On the other hand, fish and marine products is a perishable commodity after manufacture, as well as being a material of great weight loss at manufacturing, and therefore according to the economic rule contained in the theory of Alfred Weber11 (Theory) founded by the German statistical (Alfred Weber) in 1909 in his theory of endemic industries, and this theory aims to determine the good places for the concentration of industries. (Weber proposed that the cost of that the industry whose products are damaged fast must kept near markets so that it can be distributed quickly.

Pearson correlation coefficient was calculated between the number of workers in the industry and the total population in the Kingdom which reached (0.91). This confirms that processed fish represent a large part of the food components in Saudi society. Areas of the industry have been divided into three administrative regions: Eastern Province, Makkah and Riyadh. (Figure 3) and (Table 3) show that the 27 fish factories in the Kingdom of Saudi Arabia were distributed to nine sites that are centers of the fish industry in the Kingdom. The geographical distribution is characterized by the concentration pattern of the majority of factories. Two cities have a large share of the number of fish factories, with Dammam accounting for $44.4 \%$ of the total number of factories. Jeddah has $25.9 \%$ of the total number of factories, $3 \%$ of the total fish industry in the Kingdom. It is clear that the fish industry is concentrated in two regions only and the prevalence index is $8.5 \% 2$. The non-marine inland areas are excluded from this industry except Makkah, Riyadh, Al Ayoun, Qatif, Khobar and Leth. Imported products, which means that the industry is heading to raw materials (fish) which are rapidly damaged. 


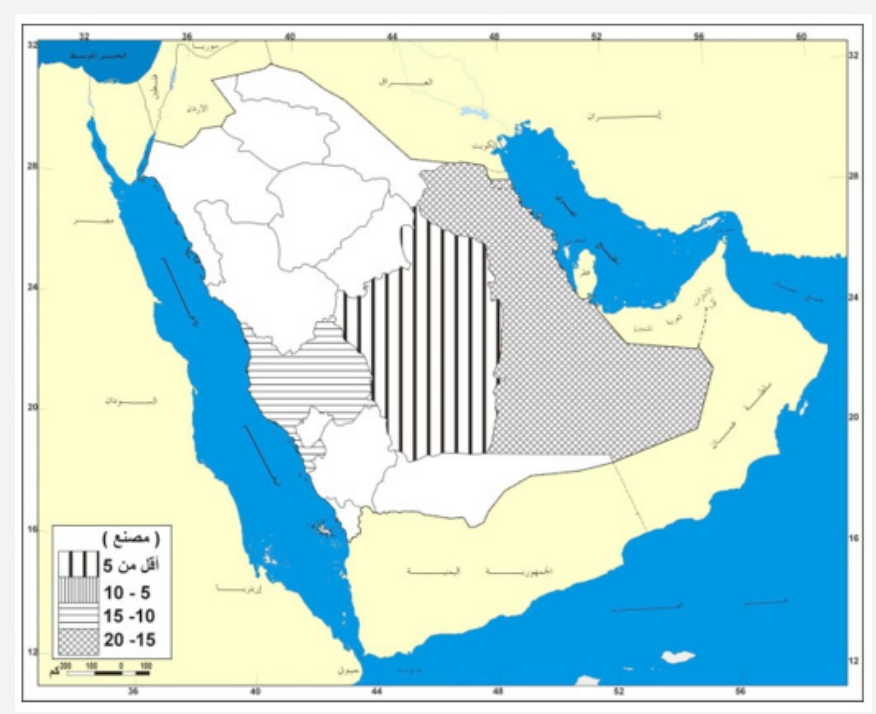

Figure 3: Fish production plants in Saudi Arabia.

Source: Prepared by the researcher based on unpublished statistical data from the Ministry of Commerce and Industry, Department of Statistics and Industrial Information, 2016.

Table 3: Geographical distribution of fish plants in cities and administrative regions In the Kingdom of Saudi Arabia for 2016.

\begin{tabular}{|c|c|c|c|}
\hline Geographical Areas & Administrative areas & Cities & Number of Factories \\
\hline \multirow{2}{*}{ Eastern Region } & & & 21 \\
& & \\
2 & 2 \\
2 & 7 \\
& Eastern areas (15 factory) & Dammam Oyoun Qatif Al Khobar & 2 \\
Western Region & & & 2 \\
& Mecca (10 factories) & Jedda Mecca Al layth Bahra & 2 \\
\hline Middle Region & Riyadh (2 factories) & & 1 \\
\hline 3 regions & 3 Regions & Riyadh & 27 \\
\hline
\end{tabular}

Source: Prepared by the researcher based on unpublished statistical data from the Ministry of Commerce and Industry, Department of Statistics and Industrial Information, 2016.

Fourth: The economic and economic characteristics of the fish industry in the Kingdom of Saudi Arabia

Table 4: Geographical and economic characteristics of the fish industry In the Kingdom of Saudi Arabia for 2016.

\begin{tabular}{|c|c|c|c|c|c|c|c|c|c|}
\hline \multirow{2}{*}{$\%$} & \multirow{2}{*}{ Production in tones } & \multirow{2}{*}{$\%$} & \multirow{2}{*}{ Investments } & \multirow{2}{*}{$\%$} & \multirow{2}{*}{$\begin{array}{c}\text { No. of } \\
\text { workers }\end{array}$} & \multirow{2}{*}{$\%$} & \multirow{2}{*}{$\begin{array}{c}\text { No of } \\
\text { factories }\end{array}$} & \multicolumn{2}{|c|}{ Geographical area } \\
\hline & & & & & & & & City & Region \\
\hline & 97162 & & 755054566 & & 220 & & 97 & Dammam & \multirow{4}{*}{ Eastern } \\
\hline & 655 & & 99615165 & & 75 & & 9 & Al Oyoun & \\
\hline & 4070 & & 72555555 & & 25 & & 9 & Al Qatif & \\
\hline & 725 & & 2455555 & & 25 & & 9 & AlKhobar & \\
\hline \multirow[t]{5}{*}{5555} & 95267 & 5555 & 742420576 & 95504 & 510 & 0050 & 90 & & Total \\
\hline & 9122220 & & 9217655095 & & 642 & & 2 & Jedda & \multirow{4}{*}{ Mecca } \\
\hline & 77559 & & 056090275 & & 655 & & 9 & AlLayth & \\
\hline & 9555 & & 772555555 & & 755 & & 9 & Bahara & \\
\hline & 1555 & & 992259421 & & 755 & & 9 & Mecca & \\
\hline 12547 & 7595606 & 56552 & 7620492270 & 52506 & 2425 & 22552 & 95 & & Total \\
\hline 9565 & 24505 & 0554 & 921555555 & 9555 & 965 & 254 & 7 & Riyadh & Riyadh \\
\hline 9565 & 24505 & 0554 & 921555555 & 9555 & 965 & 254 & 7 & & Total \\
\hline 955 & 7562565 & 955 & 2569517209 & 955 & 5450 & 955 & 72 & 1 & Total \\
\hline
\end{tabular}

Source: Prepared by the researcher based on unpublished statistical data from the Ministry of Commerce and Industry, Department of Statistics and Industrial Information, 2016. 


\section{International Journal of Environmental Sciences \& Natural Resources}
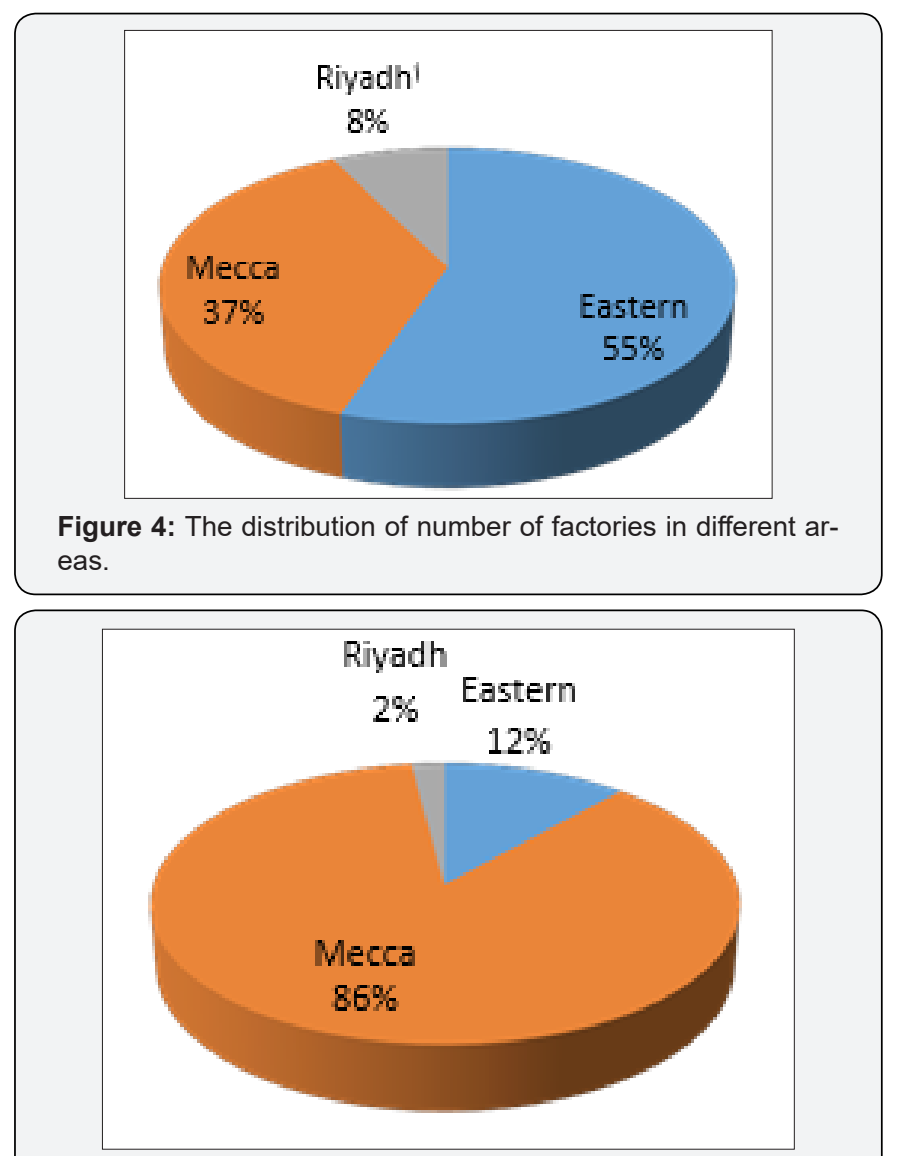

Figure 5: The distribution of number of workers in different areas.
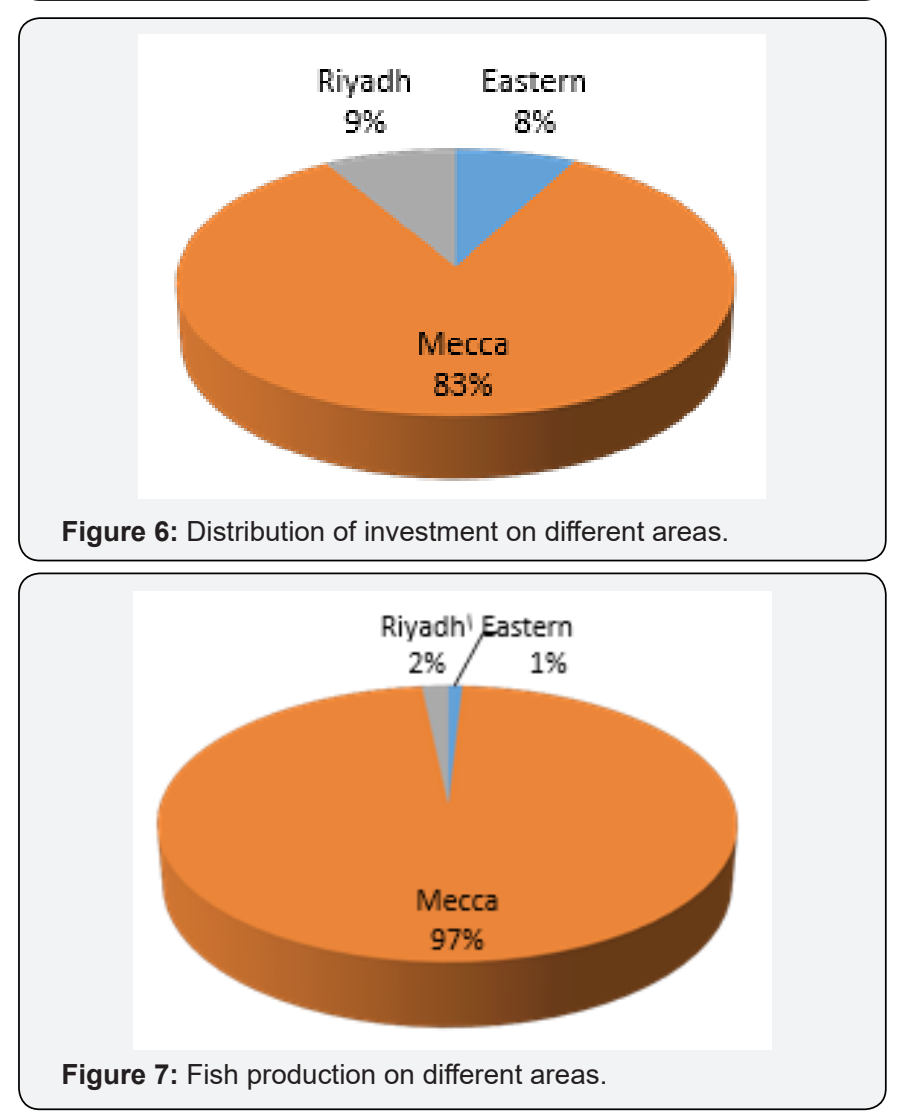

Economic geography has played an important role in the growth of the fish industry. These characteristics include the number of factories, labor and capital, as well as annual production capacity (Table 4) and (Figures 4-7).

\section{Investments}

The total number of fish factories in the Kingdom reached about 27 factories till $1437 \mathrm{H}$. The total investment of this industry amounted to about 3.61890 million riyals, which reached about 139.2 per factory, where the minimum capital of the factory was 1.19 million riyals while it was the highest capital is 1404 million riyals.

Fish factories can be classified by the investor's capital into several categories:

i. The first category: factories with investments ranging between 1 - 5 million and 5 factories.

ii. The second category: factories with investments ranging between 5 - 40 million riyals and 13 factories.

iii. The third category: factories with investments ranging from 40 to 200 million riyals and five factories.

iv. The fourth category: factories with investments of more than 200 million riyals and the number of 4 factories.

This indicates that the majority of $48.1 \%$ of the 13 mediumsized enterprises, each with a capital of between 5 and less than 40.5 million riyals. It was also found that the majority of the factories have national capital except for three factories with a common capital. Partner nationality is Jordan at 50\%. The plant is located in Dammam. Production started in 1423H (2013) with a capital of 7 million SR, 100\% foreigner from Jordan, and settled in the city of Dammam also, with a capital of 1.1 million riyals. Production started in $1435 \mathrm{AH}$. The latter is also 100\% foreign capital, which is from Egypt with a capital of 44.6 million riyals. Production started in $1430 \mathrm{H}$, and the plant is also located in Dammam.

\section{Labor}

The number of workers in Saudi fish factories reached 8505 workers, and range reached 2784, which is very large. The number of workers in the factory was 16 workers and the range number is 2,800 .

With regard to the size of factories according to manpower, the factories can be classified according to the number of workers to the following categories:

These statistical numbers illustrate the following facts:

i. The plants are small in size in terms of the workforce, which employs less than 21 workers are few, accounting for $7 \%$ of the total fish factories in Saudi Arabia.

ii. The majority of the factories fall within the middle category, which employs 21 - 50 workers in the factory, which accounted for $37 \%$. 
iii. The factories that are considered very large $101-200$ workers are accounted for $25 \%$, while factories employing more than 200 workers are representing $14 \%$.

It is worth mentioning that most of the labor in the fish industry are expat workers, while local employment size is very small and not to exceed 7.3\% (Economic and Social Commission for Western Asia, 2000, p. 104) Perhaps the reason is the small wages, which is a discouraging element to local employment in the labor market.

\section{Fifth: Localization of Fish Industry in the Kingdom}

The study of localization is one of the basic dimensions of the geographical distribution of the fish industry, because it depends on the perception of the extent to which the various components of the industry are attracted to a specific place. Location Quotient measures the degree of industrial activity in each administrative area separately compared to the general level of the Kingdom, as well as the nature of the industry to be established. If each of the country's regions has its own location Quotient factors this can determines the quality, characteristics and size of the industry.

The results of the measurement of Location Quotient are based on the number of factories indicated that the fish industry in three regions: Makkah (0.1) and the Eastern Region (0.1). These regions include Jeddah on the Red Sea coast, Dammam on the Arabian Gulf coast. Therefore, it is not surprising that it accounts for the largest share of the fish industry. Raw materials vary in their affect and level of attracting the industry depending on their location, nature, characteristics and vulnerability. Normally raw material affects the location of the fish industry and thus it is realized that only $11.5 \%$ of fish factories consume fish and lakes as basic products in their production (Al-Hurra, 2012, p. 114), and most factories rely on crude imported from abroad, because most of the domestic production is consumed as fresh or refrigerated products.

\section{Sixth: Industrial Production of Fish Industry in the Kingdom}

One study indicates that full-capacity of fish processing and processing plants are about 38\% (ESCWA, 2000, p. 104), which means that most of these factories are in the category of large factories with full machinery and advanced technology. Although Saudi consumers prefer to consume fresh fish in general, there are many types of fish and marine organisms that are not consumed fresh for economic and technical conditions. Thus, they are processed through manufacturing methods to generate products of different shapes, tastes and uses to suit different needs. The susceptibility of fish to rapid damage led to the development of ways to fish storage and conservation by drying and salting at first, yet with the expansion of markets and the development of manufacturing techniques, modern conservation methods have emerged by freezing (keeping fish frozen for up to six months at a below zero temperature), Canning by keeping in oil (there are fish species suitable for canning in the Red Sea such as tuna, sardine and mackerel such as sardines), cooking by boiling for instance, and smoking (Raghba kind for instance) where the fish are exposed to smoke to dry and then packed in the storage boxes. Some other manufacturing industries related the fish industry are to benefit from low-value products and manufacturing waste, especially with the current economic and social changes in Saudi societies, the alterations of consumer needs and the emergence of value-added taxes. Fish products are characterized with their ability to meet multiple needs in terms of processing, taste and variety.

\section{Geographical distribution of fish products}

The total number of fishes entering industrialization in terms of conversion reached 201518 tons in 2016 . The industrial products vary according to Table 5: they are as follows: Fillet, fish meat, frozen shrimp, squid, mollusks and crab, fresh fish chunks, fish powder, Smoked fish, finger fish and smoked finger fish, in the following percentage $47.6 \%, 31.8 \% 15.3 \%, 4.8 \%, 0.1 \%, 0.06 \%, 0.05$, $0.01 \%$, respectively, based on the above numbers, the preferred types of products are the fillet, fish meat and frozen shrimp, they form the most industrial products of the (94.9\%). The next part of the study attempts to address these products in detail in order to distribute them geographically on their sites so as to identify their manufacturing sites.

Table 5.

\begin{tabular}{|c|c|c|}
\hline Number of Workers & Number of factories & Percentage \\
\hline $75-95$ & 2 & $\% 2,4$ \\
\hline $21-50$ & 10 & $\% 22,5$ \\
\hline $51-100$ & 4 & $\% 94,5$ \\
\hline $101-200$ & 7 & $\% 70,1$ \\
\hline More than 200 & 4 & $\% 94,5$ \\
\hline
\end{tabular}

\section{Fresh and refrigerated fish fillets}

Fish, or Fish fillet, are cut and sliced, and the thickness of the fillet is often the body of the fish, the meat is separated from the spine, thorns and bone, the result is pure meat. It has many types based on the type of fish it is made of. The most well-liked in Saudi is the Hamour filet. The nutritional value of fillet is high because it contains all the needed elements from protein, and vitamins for humans. It also contains antioxidants. It is characterized by containing $20 \%$ protein in pure meat, which means that it is easier to digest than the rest of the meat (Food and Health, 2001, p. 36). The product represents $47 \%$ of the total fish products of the fish industry; the production of this type is mainly at the Eastern region and Mecca.

\section{Frozen and Processed Fish meat}

Freezing is one of the best ways to preserve fish if rapid freezing methods are used and if the product is stored and handled properly. In this type of fish preparation, the fish is kept frozen for up to six months at a temperature of 18 below zero, and it is known that fish meat contains a proportion of water between 60 $80 \%$ during the process of freezing most of the water turned into ice. Frozen fish are considered a good alternative to fresh fish. The rapid freezing allows the fish to be kept in excellent condition for more than eight months. When smelling them for use, it is difficult 
even for the expert to differentiate them from fresh fish. The production of frozen fish production is geographically distributed on the sites of Dammam, Qatif, Jeddah, Laith and Bahra. These sites are important centers for the preparation of processed fish.

\section{C - Frozen Shrimp}

Shrimp is a type of marine products, also known as prawns or lions, and has up to about 2000 species. Shrimp is spread in the region of Jizan south of the Red Sea and the Arabian Gulf and is caught by industrial boats through the use of seabed nets. In fishing, the bottom of the fishing area should be sand and semiflat, in order to allow towing. The shrimp contains high nutritional value such as proteins and mineral elements such as iron, copper, phosphorus and calcium along with vitamins such as vitamin D and vitamin E. This industry has achieved $15.5 \%$ of the products of the fish industry due to the demand by the Saudi consumer. Shrimp is also a component in the processing of many types of seafood that began to spread in Saudi society. Jeddah, Dammam and Riyadh are among the most important centers of such industries.

\section{Conclusion and Recommendations}

a. The quantities manufactured from fish are relatively small, and consumed locally fresh, so it is necessary to increase investment in the field of industry and preserving of fish and invest of stocks in commercial quantities.

b. The increase and development of the fish processing industry is a rising phenomenon. The current industry deserves more specialized attention, full productive capacities of large existing factories can be reached via increasing investments and the application of advanced technology to improve labor productivity.

c. The productivity of the workers from the fish industry is on the rise but there are some factors that are related to labor, the most important of which is the lack of sufficient study on the production and practical situation within the factories. More specialized studies are needed so as the indicators of productivity can be measured more accurately. d. Support the concerned authorities for fishing operations and encourage the expansion of fish farms on the beaches.

e. Encouraging fish farming from brackish water that exists in some areas of the Kingdom, whether surface or underground, in order to cover the need of fresh marine products.

Increased attention must be given to the waste of the fish industry, where these residues are suitable for the production of poultry and animal feed to enhance its use in this area that has great social and economic benefits.

\section{References}

1. Al-Gammal, Frank M, El-Bushra, El-Sayed (1986) Geographic Analysis of Manufacturing Industry in Saudi Arabia, Geo Journal 13(2): 157171.

2. Grart, Wyn (1982) The Political Economy of Industrial Policy, Butterworths, London, England, UK.

3. Hammond Robert, Patrick Mocullagh (1978) Quantiative Techniques in Geography. ( $2^{\text {nd }}$ edn) Oxford University Press, New York, USA.

4. Harvey, David (1979) “Explanation in Geography” Edward Arnold Great Britain.

5. Isard W (1995) Methods of Regional Analysis: An Introduction to Regional Science. John Wiley \& Sons.

6. Jarrett HR (1974) A Geography of Manufacturing. London, UK.

7. Mabogunie LA (1973) Manufacturing and the Geography of Development in Tropical Africa. Econ Geog 49(1): 1-20.

8. (2002) Public Establishment for Industrial Estates, The Guide to industry, Apex publishing, Muscat.

9. Qureshi, Salahuddin (1994) Regional Evaluation of Food Security systems in the Third world with special reference to Arab Countries, Research papers in Geography, The Saudi Geographical Society, Riyadh.

10. Ranken MD (2001) Food Industries Manual, Lconard, Hill Washington, USA.

11. Smith DM (1981) Industrial Iocation: An Economic Geographical Analysis, John Wiley and Sons, New York, UK.

This work is licensed under Creative Commons Attribution 4.0 License DOI: 10.19080/IJESNR.2018.15.555919

\section{Your next submission with Juniper Publishers will reach you the below assets}

- Quality Editorial service

- Swift Peer Review

- Reprints availability

- E-prints Service

- Manuscript Podcast for convenient understanding

- Global attainment for your research

- Manuscript accessibility in different formats

( Pdf, E-pub, Full Text, Audio)

- Unceasing customer service

Track the below URL for one-step submission https://juniperpublishers.com/online-submission.php 